Review

\title{
Contextualization of the Bioeconomy Concept through Its Links with Related Concepts and the Challenges Facing Humanity
}

\author{
Leire Barañano $^{1,+}$, Naroa Garbisu ${ }^{2,+}$, Itziar Alkorta ${ }^{3} \mathbb{D}$, Andrés Araujo ${ }^{4}$ and Carlos Garbisu ${ }^{1, *(D)}$ \\ 1 NEIKER-Basque Institute of Agricultural Research and Development, Parque Científico y Tecnológico de \\ Bizkaia P812, 48160 Derio, Spain; lbaranano@neiker.eus \\ 2 Faculty of Economics and Business (Sarriko), University of the Basque Country (UPV/EHU), \\ 48015 Bilbao, Spain; naroa.garbisu@gmail.com \\ 3 Department of Biochemistry and Molecular Biology, University of the Basque Country (UPV/EHU), \\ P.O. Box 644, 48080 Bilbao, Spain; itzi.alkorta@ehu.eus \\ 4 Department of Management and Business Economics, University of the Basque Country (UPV/EHU), \\ 48015 Bilbao, Spain; andres.araujo@ehu.eus \\ * Correspondence: cgarbisu@neiker.eus \\ + Both authors contributed equally to this study.
}

Citation: Barañano, L.; Garbisu, N.; Alkorta, I.; Araujo, A.; Garbisu, C. Contextualization of the Bioeconomy Concept through Its Links with Related Concepts and the Challenges Facing Humanity. Sustainability 2021, 13, 7746. https://doi.org/10.3390/ su13147746

Academic Editor: Luis Jesús Belmonte-Ureña

Received: 31 May 2021

Accepted: 8 July 2021

Published: 12 July 2021

Publisher's Note: MDPI stays neutral with regard to jurisdictional claims in published maps and institutional affiliations.

Copyright: (c) 2021 by the authors. Licensee MDPI, Basel, Switzerland. This article is an open access article distributed under the terms and conditions of the Creative Commons Attribution (CC BY) license (https:// creativecommons.org/licenses/by/ $4.0 /)$.

\begin{abstract}
The concept of bioeconomy is a topic of debate, confusion, skepticism, and criticism Paradoxically, this is not necessarily a negative thing as it is encouraging a fruitful exchange of information, ideas, knowledge, and values, with concomitant beneficial effects on the definition and evolution of the bioeconomy paradigm. At the core of the debate, three points of view coexist: (i) those who support a broad interpretation of the term bioeconomy, through the incorporation of all economic activities based on the production and conversion of renewable biological resources (and organic wastes) into products, including agriculture, livestock, fishing, forestry and similar economic activities that have accompanied humankind for millennia; (ii) those who embrace a much narrower interpretation, reserving the use of the term bioeconomy for new, innovative, and technologically-advanced economic initiatives that result in the generation of high-added-value products and services from the conversion of biological resources; and (iii) those who stand between these two viewpoints. Here, to shed light on this debate, a contextualization of the bioeconomy concept through its links with related concepts (biotechnology, bio-based economy, circular economy, green economy, ecological economics, environmental economics, etc.) and challenges facing humanity today is presented.
\end{abstract}

Keywords: bio-based economy; biotechnology; circular economy; green economy; sustainability; sustainable development goals

\section{Introduction \\ 1.1. Environmental Degradation}

Environmental degradation, a matter of great concern, implies a depletion of natural resources (e.g., air, water, soil, forest, wildlife) and ecosystem services. Environmental degradation can include physicochemical effects (alteration of the land surface, contamination), aesthetic effects (scenic degradation), and biological-ecological effects (deforestation, loss of biodiversity). At the present time, humanity's ecological footprint is such that some scientists have declared the dawning of a new geological epoch-the Anthropocene. Wellknown outcomes of environmental degradation are famines, poverty, wars, human right abuses, political instability, and deterioration of human health. Two of the main causes behind the effects of the present environmental degradation (e.g., climate change, pollution, biodiversity loss, desertification, ocean acidification, deforestation) are overpopulation and over-consumption, both connected to the discovery of fossil fuels. The discovery of fossil fuels allowed the exponential growth of the human population and the spread of 
consumerism, together with unprecedented economic, social, and technological progress. Regrettably, this unparalleled period of socioeconomic growth has been, to a great extent, achieved at the expense of environmental degradation.

Driven by mounting concern over the "environmental quagmire", governments, economic institutions, and civil society organizations are proposing new paradigms of economic thinking, aimed at a more sustainable and ethical economy.

\subsection{Bioeconomy}

In this context, the concept of bioeconomy, a subdivision of the economy based on biology and biosciences $[1,2]$, emerged with great expectations regarding its potential to lead the way towards a sustainable future. Bioeconomy is being supported in research and policy strategies with the goal of developing a sustainable economic paradigm that encourages the creation of innovative value chains, while protecting the environment. Three factors that have contributed to interest in bioeconomy are: advances in biological sciences; policy objectives for climate change mitigation, energy self-sufficiency, rural development, and export promotion; and the fact that biodiversity and genetic resources are viewed as inputs critical to the discovery of pharmaceuticals and other bio-based products [3].

However, some authors claim that bioeconomy is nothing but a "master narrative" that conflates technological advances with societal progress [4] or a political project with spurious interests [5]. Birner (2018) [6] distinguishes between two types of criticism of the bioeconomy field: (i) the fundamental critique, supported by authors, such as Birch and collaborators $(2006,2010)[7,8]$, who claim that bioeconomy is the "neoliberalization of nature" and consider that its development is dominated by a "neoliberal ideology" in which market values are installed as the over-riding ethic in society. Similarly, Gottwald and Budde (2015) [9] consider that bioeconomy is promoted to pursue the interests of large companies involved in commercializing innovations in the life sciences and are worried that bioeconomy will promote "land grabbing" and threaten food security and nature conservation; and (ii) the greenwashing critique [10], which emphasizes that many initiatives promoted under the bioeconomy label are not environmentally sustainable. Although it is beyond the purpose of this manuscript to enter such political-ethical debates, the reality is that, depending on how it is pursued, the bioeconomy transition may either address fossil fuel dependence sustainably or aggravate human pressure on the environment [11]. As an example, Bastos Lima (2021) [11] has reported how corporate agribusiness dominance limits the bioeconomy agenda, shapes innovation pathways, and ultimately threatens the sustainability of this transition.

In the last years, many definitions of bioeconomy have been proposed. Table 1 includes some of the most commonly used definitions of bioeconomy proposed by the OECD and other relevant institutions.

There are three visions of bioeconomy [12]: (i) bio-technology vision, focusing on the importance of biotechnology for different sectors of the economy; (ii) bio-resource vision, centering on the processing and upgrading of biological raw materials; and (iii) bio-ecology vision, which is directed towards environmental sustainability, the promotion of biodiversity, and the protection of nature. 
Table 1. Definitions of bioeconomy.

\begin{tabular}{|c|c|}
\hline Definition & Reference \\
\hline $\begin{array}{l}\text { A world in which biotechnology contributes to a significant share of economic } \\
\text { output. The emerging bioeconomy is likely to involve three elements: the use of } \\
\text { advanced knowledge of genes and complex cell processes to develop new } \\
\text { processes and products, the use of renewable biomass and efficient bioprocesses } \\
\text { to support sustainable production, and the integration of biotechnology } \\
\text { knowledge and applications across sectors. }\end{array}$ & [13] \\
\hline $\begin{array}{l}\text { The production of renewable biological resources and the conversion of these } \\
\text { resources and waste streams into value-added products, such as food, feed, } \\
\text { bio-based products and bioenergy. }\end{array}$ & [14] \\
\hline $\begin{array}{l}\text { The production, utilization and conservation of biological resources, including } \\
\text { related knowledge, science, technology and innovation, to provide information, } \\
\text { products, processes and services across all economic sectors, aiming toward a } \\
\text { sustainable economy. }\end{array}$ & [15] \\
\hline $\begin{array}{l}\text { The knowledge-based production and use of biological resources to provide } \\
\text { products, processes and services in all economic sectors within the frame of a } \\
\text { sustainable economic system. }\end{array}$ & [16] \\
\hline
\end{tabular}

Regarding this last vision, bioeconomy has been proposed as a relevant part of the solution to the Grand Challenges of the 21st century (e.g., climate change, food and water security and safety, energy security, global contamination). One of the early promises of bioeconomy was to reduce our dependence on fossil fuels. The idea was to navigate the required transition from a fossil-fuel-dependent economy towards a bioeconomy supported by bio-based and recirculated products and renewable energy [17]. It must be emphasized that sustainability is not attainable simply by using renewable resources. Among other aspects, the sustainability goal requires the sustainability of the resource base, the sustainability of production and consumption processes, and the circularity of material fluxes $[17,18]$. In Europe, the sustainability-related expectations associated with bioeconomy were developed in response to a growing concern about enhancing competitiveness in a global market [19] and also due to the conviction that Europe must lead the transition to a climate-neutral society. Sustainability is certainly not achieved merely by using renewable resources, but it is also an incontestable fact that, in a world characterized by finite resources and human population growth, renewability appears to be a good idea.

Despite different definitions, there seems to be a consensus that the term bioeconomy refers to the sustainable use of renewable biological resources and organic wastes to produce food, feed, bio-based products, and bioenergy. Regardless of this consensus, the reality is that the bioeconomy concept is still a topic of debate among politicians, scholars, and entrepreneurs. The confusion, skepticism and criticism associated to the bioeconomy concept are driving this debate and, not surprisingly, stimulating a productive exchange of information, ideas and values, with beneficial effects on the development of the bioeconomy paradigm. At the core of this debate, three points of view coexist: (i) those who support a broad interpretation of the term bioeconomy, through the incorporation of all economic activities based on the production and conversion of renewable biological resources into products, including agriculture, livestock, fishing, forestry and similar economic activities that have accompanied humankind for millennia; (ii) those who embrace a much narrower interpretation, reserving the use of the term only for innovative and technologically-advanced economic initiatives that result in the generation of high-added-value products and services from the conversion of renewable biological resources; and (iii) those who stand between these two viewpoints.

In any case, bioeconomy activities can be classified as natural-resource-based activities that directly exploit bioresources (agriculture, fishery, forestry) and provide biomass for further processing; conventional manufacturing activities that further process biomass (food 
sector, wood processing sector); and novel activities that further process the biomass and/or biomass residues (bioenergy sector, bio-based chemical sector) [20].

\subsection{Circular Bioeconomy}

According to the European Commission [21], circular economy aims to (i) maintain the value of products, materials, and resources in the economy for as long as possible (by returning them, at the end of their use, to the product cycle); and (ii) minimize the generation of waste. The idea is to reduce the number of resources we use, the quantity of materials we extract, the number of products we discard, and the amount of waste we generate as much as possible. As an alternative to the "take-make-waste" model characteristic of the linear economy, the Ellen MacArthur Foundation played a key role in the definition of circular economy, based on the following principles: design out waste and pollution, keep products and materials in use, and regenerate natural systems. Circular economy distinguishes between technical and biological cycles: technical cycles are aimed at recovering and restoring products, components and materials through strategies such as reuse, repair, remanufacture or, in the last resort, recycling; and biological cycles, where bio-based materials are recycled back into manufacturing and, finally, fed back into nature through processes such as, for instance, composting for the production of soil amendments.

The circular economy concept has developed the principles of different schools of thought in a narrative that can inspire policy actions, evoked a socio-technical transition in which societal and material needs are fulfilled by novel industrial systems, and contributed to the environmental and economic dimensions of sustainability [22]. Nonetheless, at the market level, the full potential of circular economy is far from being realized and needs to develop further evidence that circular-economy-inspired products are preferable [23].

The transition towards bioeconomy depends not only on the efforts of professionals and policymakers but also on the acceptance and involvement of society [24] -in particular, consumers. In a study among Dutch and Irish consumers [25], price was indicated as a key factor influencing the purchase of bio-based products (around half of consumers were unwilling to pay more for bio-based products). Consumers indicated that environmental sustainability is a significant factor when choosing between products, but biodegradability and compostability are more important aspects for them than bio-based origin, highlighting the need to improve consumer understanding of bio-based products [25]. Transparent legal status and legislation are also critical factors for the development of bioeconomy [24].

Regarding circularity, the degradation of natural resources points out to the need to change our linear economic approach by shifting from the use of non-renewable resources towards a bioeconomy based on renewable resources. The linear economic approach is structured around two pillars: depletable fuels and materials as input, and products and contaminating substances as output [26]. Circular bioeconomy is characterized by biofuels and biomaterials as input and recyclable products as output [27]. Within the bioeconomy field, the archetypal example of circularity is as follows: solar energy is transformed into biomass; biomass is converted into products; and the residual waste is used as organic fertilizer, turned into food or animal feed, or used to supply energy. To guarantee circularity, the process must operate according to a cascading model [28,29]: (i) biomass (generated from solar energy) is converted into products; (ii) the waste stream of this process is used as a supply stream for a lower-level production process; (iii) this latter process is repeated until the waste stream can no longer be transformed into products; and (iv) waste is incinerated to provide energy to different steps within the closed loop [26]. In this way, bioeconomy should be the epitome of the "zero-waste" goal.

In the last years, we have witnessed the merging of circular economy and bioeconomy, resulting in the concept of circular bioeconomy focused on a sustainable valorization of biomass, while making use of wastes and optimizing the value of biomass over time [30]. To ensure that biomass is used sustainably, bioeconomy must include strategies from circular economy (e.g., the re-cycling of bio-based products) [31]. Although it is claimed that bioeconomy is circular by nature (based on the fact that nature is circular by definition 
and that bioeconomy is inspired by natural regeneration), the veracity of such a statement depends on the specific treatments and uses given to the biomass. For instance, to claim circularity and sustainability, we must guarantee that biomass is used for a higher value purpose than simply energy generation through incineration. A sustainable circular bioeconomy must maintain resources at their highest value for as long as possible through cascading biomass use and recycling, while protecting natural capital and the provision of ecosystem services.

The sustainability of bio-based products must be assessed over their life cycle and must incorporate the sustainability of the resource base and the sustainability of processes and products [17]. The Life Cycle Sustainability Assessment (LCSA) brings together analyses of the three dimensions of sustainability, employing life cycle thinking across intersecting supply chains [32]. The LCSA can be developed for product development, strategic planning, and public policy making, considering whole system cradle-to-cradle supply chains $[32,33]$.

Another possibility to evaluate the sustainability of bioeconomy initiatives is to analyze them not only via Life Cycle Assessment but also through the United Nations Sustainable Development Goals (SDGs) lens [34]. One way to ensure the sustainability of bioeconomy initiatives would be by linking their reporting with the SDGs related to economic development, access to basic services, sustainable consumption, biodiversity conservation, waste re-use, equality, gender equality, inclusiveness and international cooperation [35]. Since information access is a challenge related to all the SDGs, Bicchielli et al. (2021) [36] reported an ontology (BiOnto) for sustainable bioeconomy, taking into account approaches related to sharing knowledge on bioeconomy and collaborative ecosystems.

In the light of the potential of circular bioeconomy to address many of the Grand Challenges of the 21st century, many governments and regions have elaborated strategic plans to drive the transition from a linear fossil fuel-based economy to a sustainable circular bioeconomy, in order to increase competitiveness in a global market that demands sustainable production-consumption systems, while contributing to the SDGs. However, after reviewing many national and regional bioeconomy strategies, Staffas et al. (2013) [37] concluded that sustainability issues were underplayed in many of those strategies. D'Amato et al. (2017) [38] and Ramcilovic-Suominen and Pülzl (2018) [39] concluded that bioeconomyrelated policies have been more oriented towards economic growth, without considering the environmental and social aspects of sustainability in the same depth.

\subsection{Regional Bioeconomy}

There is growing interest with respect to the use of regional strategies as the focus of bioeconomy [19]. Many regional bioeconomy initiatives have emerged in the past years. In many cases, these initiatives are supported by the establishment of private-public partnerships driven by the will to invest in the generation of technologies and products required to advance the expansion of bioeconomy. In Europe, regions are considered as the main driver for a successful implementation of sustainable circular bioeconomy [40]. In consequence, a mapping of the competencies of bioeconomy in EU regions is essential to create innovative bioeconomy value chains. The BERST Tool (https:/ / berst.databank.nl/; accessed on 9 July 2021), designed during the development of the EU Horizon 2020 Project "Building Regional Bioeconomies", identifies four pillars of bioeconomy readiness in a region: biomass availability and land use, demographics and the quality of the workforce, employment and the structure of firms, and innovation. It has been reported [41] that pursuing a more regional approach to bioeconomy can be a promising way forward due to its bridging function between the international and national level. In addition, there is frequently greater similarity between challenges and opportunities within a region and an easier exchange of lessons learnt [41].

In this regard, bioeconomy is linked with the concept of bioregionalism, which claims that economic, social, cultural, and political systems are more sustainable when organized according to naturally defined areas called bioregions [42]. Bioregionalism proposes 
natural regions as organizing units for human activity. Bioregions can be delineated by four approaches [43]: (i) an environmental determinist position, according to the view that nature determines culture within the context of specific regions; (ii) a correspondence position, which assumes that there is a correspondence between nature and culture at the bioregional scale; (iii) a possibilist position, which asserts that geography simply sets certain limits and/or provides resources, and that regions are predominantly the product of culture; and (iv) a consciousness position, where boundaries are not set in line with geographical or natural considerations but are emotionally established by human perception and thoughts.

When assessing the potential of a region for bioeconomy, one must pay attention not only to the amount and rate of generation of biological resources in that region but, importantly, to its capacities in terms of innovation and entrepreneurship. Many regional bioeconomy initiatives are supported by the creation of bioeconomy clusters. In any case, region-specific socioeconomic and ecological settings, legal frameworks, social demands, and the history of using natural resources must be reflected in the development of bioeconomy at a regional level [40]. Additionally, we must not forget that biomass is a renewable but limited resource as its production requires land and other resources, such as water and nutrients [44]. It is crucial to take the state of the biological resources, as well as their vulnerability against disturbances and disasters, into consideration.

For bioeconomy to successfully develop in a given region, it is vital to combine strategies that provide visions of knowledge-driven technology innovation, strategies that provide visions of the required transformational changes in governance systems to meet the targeted sustainability goals of bioeconomy, and a public goods-oriented approach $[37,45,46]$.

The objective of this paper is to describe a variety of concepts (e.g., bioeconomics, biotechnology, bio-based economy, biorefineries, green chemistry, etc.) that are linked to the field of bioeconomy, in order to better differentiate those concepts and, additionally, help develop the bioeconomy framework. Subsequently, the potential contribution of bioeconomy to the Grand Challenges of the 21st century is briefly discussed, emphasizing the need for bioeconomy to incorporate six critical sustainability issues (i.e., limits to growth, planetary boundaries, resilience thinking, ecosystem services, ecological footprint, and environmental bioethics) if it is to survive in the long-term as a driver of the economy, providing goods and services in an environmentally friendly way. The final aim is to provide a reflection on how bioeconomy should contribute to a sustainable, ethical and prosperous society.

\section{Methodology}

In this paper, a contextualization of the bioeconomy concept through its links with related concepts is presented. For this purpose, a literature review was carried out, according to the snowball method [47], to identify such concepts, paying special attention to the theoretical and practical differences among them. The literature review began with documents that included the most commonly used definitions of bioeconomy. Given the scope of this journal, much emphasis was paid on sustainability issues. In this line of thought, some of the most relevant sustainability frameworks developed during the last decades (i.e., limits to growth, planetary boundaries, resilience thinking, ecosystem services, ecological footprint, and environmental bioethics) are presented to emphasize the need to assimilate them if bioeconomy is to survive as a driver of our economy in the long-term (Figure 1). 


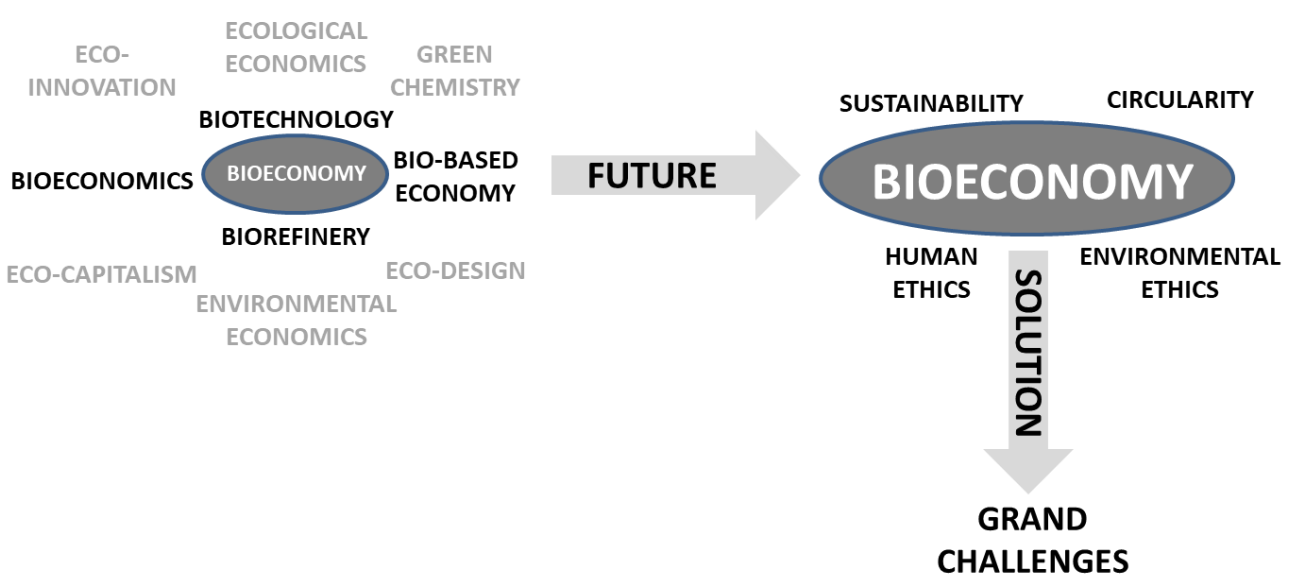

Figure 1. Visual representation of the paper.

\section{Links between Bioeconomy and Related Concepts}

The concept of bioeconomy is historically and theoretically related to a wide variety of concepts belonging to different disciplines, predominantly within economics and biology. First of all, it is important to distinguish bioeconomy from bioeconomics. The field of bioeconomics precedes the appearance of the bioeconomy concept in the literature. The term bioeconomics was probably used for the first time in 1913 by Hermann Reinheimer in his work "Evolution by Co-operation: A Study in Bioeconomics" [48]. During the first half of the 20th century, Alfred James Lotka defined bioeconomics, or biophysical economics, as the profound correlation between biological laws and thermodynamic laws inside the competition for energy and material resources [49]. In the late 1960s, Jiri Zeman used this term to emphasize the biological bases of almost all economic activities [50]. In the next decade (1970s), Nicholas Georgescu-Roegen (1977) [51-53] was responsible for the increased attention and momentum given, at the time, to bioeconomics, especially due to his concern that unlimited economic growth would not be compatible with the basic laws of nature [6]. Nicholas Georgescu-Roegen was one of the first, if not the first, economists to exhaustively study the interplay between economic activity and the environment, mainly in light of thermodynamics. He even dared to propose a Fourth Law of Thermodynamics to highlight the role played by matter as a material scaffold in modern production processes, as reflected in his famous aphorism "matter, matters too" [52,53]; for a critique, see [54]. He emphasized the problems associated with the limited stock of resources, which are unevenly found and unequally appropriated [54].

Unlike bioeconomics, the term bioeconomy, in its early days, referred to the use of biological knowledge for industrial applications [6]. Joachim von Braun (Director of the Center for Development Research, Bioeconomy Council, Bonn, Germany) stated that bioeconomy was first defined by two geneticists, Juan Enríquez-Cabot and Rodrigo Martínez, in 1997 [55,56]. In 1998, Juan Enríquez-Cabot [57] championed the idea that the application of biological and biotechnological discoveries would change the world's economy, transforming a wide variety of industrial processes, as pointed out by Glick in the early 1980s [58]. In this line of thought, in 2002, the European Commission characterized the life sciences and biotechnology as probably the most promising of the frontier technologies able to provide a major contribution to achieving the Lisbon Summit's objective of becoming a leading knowledge-based economy [5,59]. A few years later, the Report "European BioPerspectives: En Route to the Knowledge-Based Bioeconomy" stated that bioeconomy could transform life sciences knowledge into new, sustainable, eco-efficient and competitive products [60]. Later, this initial meaning of the term bioeconomy was "politically transformed" into its current meaning, i.e., the use of renewable biological resources and organic wastes to produce bio-based products and bioenergy. A pioneer in promoting bioeconomy in Europe was Christian Patermann (at that time, Program Director of Biotechnology, Agriculture and Nutrition in the Directorate General for Research, Science and Education of the European 
Commission), who realized the concept's potential to address the challenges of the European economy by making the most of the myriad of opportunities offered by advancements in biology and biotechnology [6]. In the EU, the label "knowledge-based" was often added to the term "bioeconomy" to highlight the importance of research and innovation to boost the development of the bioeconomy market.

Most likely, the concept of bioeconomics evolved towards the bioeconomy paradigm that was first focused on the application of biological and biotechnological knowledge to transform the economy and pay attention to the possibility of replacing fossil-based resources with bio-based resources.

As such, it is not surprising that, at the beginning, there was some confusion regarding the difference between bioeconomy and biotechnology. As is usually the case, many definitions of biotechnology can be found in the literature. Table 2 includes some of the most commonly used definitions of biotechnology proposed by the OECD and other relevant institutions.

Table 2. Definitions of biotechnology.

\begin{tabular}{lc}
\hline \multicolumn{1}{c}{ Definition } & Reference \\
\hline $\begin{array}{l}\text { The application of scientific and engineering principles to the processing of } \\
\text { materials by biological agents to provide goods and services. }\end{array}$ & [61] \\
\hline $\begin{array}{l}\text { The integrated use of natural sciences and engineering sciences by the } \\
\text { application of biosystems - cells of microbial, plant and animal origin, parts } \\
\text { thereof and molecular analogues-in bioindustries / The integration of natural } \\
\text { science and organisms, cells, parts thereof, and molecular analogues for } \\
\text { products and services. }\end{array}$ & [62] \\
\hline $\begin{array}{l}\text { The application of biological organisms, systems, or processes in various } \\
\text { industries to learning about the science of life and the improvement of the value } \\
\text { of materials and organisms such as pharmaceuticals, crops, and livestock. }\end{array}$ \\
\hline
\end{tabular}

Simply speaking, the term biotechnology refers to the use of biological systems and processes to make products and services. In any event, the application of innovative tools from the fields of molecular biology and biotechnology, together with green chemistry methodologies, are key for the generation of competitive bioeconomy products.

On the other hand, the terms bioeconomy and bio-based economy are often used interchangeably. Nonetheless, Staffas et al. (2013) [37] differentiate them, stating that a bio-based economy takes into consideration the production of non-food goods, whilst bioeconomy covers both bio-based economy and the production and use of food and feed. According to Zwier et al. (2015) [26], bioeconomy and bio-based economy frame economic problems in terms of efficient production and exclude the fundamental issues of abundance and wastefulness (ultimately undermining the concepts themselves by pushing the regeneration capacity of bioresources into a cataclysmic and terminal discharge). These authors argue for the introduction of the question of abundance and wastefulness into bioeconomy/bio-based economy discussions.

Another highly related concept is that of biorefineries, which emerged from concerns regarding our dependence on fossil fuel refinery for the production of energy and material products. In light of the environmental consequences of our dependence on fossil fuels, together with their uncertain availability in the long-term, the development of biorefineries was materialized to replace oil with biomass as raw material for fuel and chemical production. Almost all types of biomass feedstocks can be converted to biofuels and biochemicals via a variety of conversion technologies [64]. A biorefinery is a facility with integrated, efficient and flexible conversion of biomass feedstocks, through a combination of physical, chemical, biochemical and thermochemical processes, into multiple products [33]. Biorefineries apply a variety of technologies to separate biomass resources into their building blocks, which can then be converted to chemicals and biofuels. Preferably, feedstocks that have minimum or no conflict with land use should be used, such as agricultural and 
forestry residues, garden wastes, oily residues, aquatic biomass, organic residues, and unavoidable food waste $[33,65]$. In this respect, it has been claimed that integrated marine biorefinery systems might be economically more attractive than lignocellulosic terrestrial biorefinery systems, and that integrated macroalgae biorefineries can confront many of the SDGs [66]. Together, bioenergy, biorefinery and bioeconomy can play an important role in strengthening resilience against climate change and natural disasters, adopting sustainable production and consumption, conserving natural resources, and embracing green growth [67]. Green chemistry (i.e., a set of principles for the manufacture and application of products aimed at eliminating the use or generation of environmentally harmful and hazardous chemicals) [64] plays a key role in the development of biorefineries. The combination of green chemistry and biorefinery aims to produce green, non-toxic, and degradable chemical products, with minimum production of waste.

From an an economics perspective, all these approaches are encompassed by the fields of environmental economics and ecological economics, which share the goal of understanding "human-economy-environment" interactions in order to redirect the economy towards sustainability [68]. Environmental economics has followed a narrowly focused neoclassical analytical approach, which has been more effective from a policymaking perspective (in contrast, ecological economics embraced a diversified, pluralistic approach, which has resulted in an overwhelmingly challenging strategy) [68]. Another difference between these two fields of economic knowledge is that the majority of environmental economists are initially trained as economists, while ecological economists are usually trained as ecologists. The former approach envisions environmental economics as a sub-topic of economics dealing with environmental issues, while the latter emphasizes that economy is a subsystem of the ecosystem, with its focus being to preserve natural capital (according to the premise that economics is a subfield of ecology) [69]. The conceptual core of ecological economics (i) combines ecological understanding, social structure, and a redefined economics; (ii) recognizes the dependence of economic and social structures on biophysical reality; (iii) challenges mainstream economists to move beyond their orthodox points of views; (iv) rejects the growth paradigm (for a critique of economic growth, based on physics, see [70]); and (v) has ontological foundations that inform it as a paradigm both biophysically and socially [64]. This paradigm (and related paradigms such as, for instance, social ecological economics [71,72]) emerged from recognition of the systemic problems of the traditional economic system (e.g., increasing inequity, social division, loss of biodiversity, pollution of ecosystems, and resource wars).

Ecological economics [73] is interrelated with the concept of eco-capitalism (or environmental or green capitalism), which supports the belief that capital exists in nature as "natural capital" on which all wealth depends. In this context, the economic value of ecosystems and biological diversity, as well as the importance of reducing human environmental impacts, is highlighted. The proponents of eco-capitalism see loss of biodiversity, contamination and resource overexploitation as a form of market malfunction derived from the failure of capitalist systems to account for the financial value of environmental services [74].

All these eco-economic approaches are required for theoretical and practical advancements in the field of eco-innovation (or environmental innovation) (Table 3). 
Table 3. Definitions of eco-innovation.

\begin{tabular}{lc}
\multicolumn{1}{c}{ Definition } & Reference \\
\hline $\begin{array}{l}\text { Innovation that serves to prevent or reduce anthropogenic burdens on the } \\
\text { environment, clean up damage already caused, or diagnose and monitor } \\
\text { environmental problems. }\end{array}$ & {$[75]$} \\
\hline $\begin{array}{l}\text { A process in which sustainability considerations are integrated into company } \\
\text { systems from idea generation through to R\&D and commercialization. }\end{array}$ & {$[76]$} \\
\hline $\begin{array}{l}\text { Any form of innovation aiming at significant and demonstrable progress } \\
\text { towards the goal of sustainable development, through reducing impacts on the } \\
\text { environment or achieving a more efficient and responsible use of natural } \\
\text { resources, including energy. }\end{array}$ & {$[77]$} \\
\hline $\begin{array}{l}\text { Innovations that consist of new or modified processes, practices, systems and } \\
\text { products that benefit the environment and so contribute to environmental } \\
\text { sustainability. }\end{array}$ & {$[78]$} \\
\hline Innovation that improves environmental performance.
\end{tabular}

Eco-innovation deals with the development of new technologies, processes and systems to improve the environmental performance of economic activities. Díaz-García et al. (2015) [80] proposed that the use of this term should imply a full-life cycle analysis of input and output factors. A similar but not identical concept is eco-design [80], the most accepted definition of which is "Integration of environmental aspects into product design and development, with the aim of reducing adverse environmental impacts throughout a product's life cycle" (ISO 14006:2011 Norm: Environmental Management Systems-Guidelines for Incorporating Ecodesign). Unlike eco-design, which is a well-established concept as reflected by the existence of ISO 14006:2011, Cluzel et al. (2014) [81] reported that the concept of eco-innovation remains poorly understood, with theoretical uncertainties and a lack of a standardized definition.

All these abovementioned concepts (Table 4) are directed towards an economic model that guarantees environmental, social and economic sustainability and that can face the Grand Challenges of the 21st century.

Table 4. Concepts related to bioeconomy. Descriptions have been extracted from the text.

\begin{tabular}{cl}
\hline Concept & \multicolumn{1}{c}{ Description } \\
\hline Highly related & $\begin{array}{l}\text { Bioeconomics or biophysical economics refers to the profound correlation between biological laws } \\
\text { and thermodynamic laws in the competition for energy and material resources. It emphasizes the } \\
\text { biological origin of the economic process and the problems associated with the limited stock of } \\
\text { resources. }\end{array}$ \\
\hline Bioeconomics & Biotechnology refers to the use of biological systems and processes to make products and services. \\
\hline Biotechnology & $\begin{array}{l}\text { The terms bioeconomy and bio-based economy are used interchangeably. However, some authors } \\
\text { differentiate them, stating that bio-based economy takes the production of non-food goods into } \\
\text { consideration, whilst bioeconomy covers both bio-based economy and the production and use of } \\
\text { food and feed. }\end{array}$ \\
\hline Bio-based & $\begin{array}{l}\text { A facility with integrated, efficient and flexible conversion of biomass feedstocks, through a } \\
\text { combination of physical, chemical, biochemical and thermochemical processes, into } \\
\text { multiple products. }\end{array}$ \\
\hline Biorefinery & $\begin{array}{l}\text { A set of principles for the manufacture and application of products aimed at eliminating the use } \\
\text { or generation of environmentally harmful and hazardous chemicals. }\end{array}$ \\
\hline $\begin{array}{c}\text { Geen related } \\
\text { chemistry }\end{array}$ &
\end{tabular}


Table 4. Cont.

\begin{tabular}{cl}
\hline Concept & \multicolumn{1}{c}{ Description } \\
\hline $\begin{array}{c}\text { Environmental } \\
\text { and ecological } \\
\text { economics }\end{array}$ & $\begin{array}{l}\text { Environmental economics and ecological economics share the goal of understanding } \\
\text { "human-economy-environment" interactions, in order to redirect the economy towards } \\
\text { sustainability. The majority of environmental economists are initially trained as economists, while } \\
\text { ecological economists are usually trained as ecologists. Environmental economics is a sub-topic of } \\
\text { economics dealing with environmental issues. For ecological economists, the economy is a } \\
\text { subsystem of the ecosystem, with a focus on preserving natural capital. }\end{array}$ \\
\hline Eco-capitalism & $\begin{array}{l}\text { Eco-capitalism (or environmental or green capitalism) supports the belief that capital exists in nature } \\
\text { as "natural capital" on which all wealth depends. }\end{array}$ \\
\hline Eco-innovation & $\begin{array}{l}\text { It deals with the development of new technologies, processes and systems to improve the } \\
\text { environmental performance of economic activities. }\end{array}$ \\
\hline Eco-design & $\begin{array}{l}\text { Integration of environmental aspects into product design and development, with the aim of } \\
\text { reducing adverse environmental impacts throughout a product's life cycle. }\end{array}$ \\
\hline
\end{tabular}

\section{Bioeconomy and the Grand Challenges Facing Humanity}

\subsection{The Grand Challenges}

In the 21st century, our planet is under serious stress from a variety of inter-linked factors associated with increasing global population, linear resource consumption, security of resources, unsurmountable waste generation, and social inequality [65]. It is often claimed that bioeconomy can be a part of the solution to the Grand Challenges of the 21st century, e.g., climate change, food and water security and safety, energy security, overpopulation, global contamination and biodiversity loss. Before examining this claim, it is important to remember that, paradoxically, some of the very same Grand Challenges of the 21st century are most likely going to hinder the development of bioeconomy. After all, many bioeconomy aspirations and expectations depend on a constant supply of great amounts of biomass. If we take into consideration that (i) $50-70 \%$ more food will be needed by 2025 to feed the growing human population [82]; (ii) climate-change-induced extreme heat waves and droughts will increasingly have an adverse impact on agricultural crop yields; and (iii) the progressive degradation of the soil resource, it is easy to anticipate one of the biggest conundrums for bioeconomy: how to reconcile the competing needs of agriculture and bioeconomy $[83,84]$ without forgetting that food security takes priority. It is true that, historically, many, if not most, similar transitions took a very long time to be completed and also faced technical and political difficulties, but the proposed bioeconomy transition is probably expected to be fraught with more setbacks and obstacles as a consequence of the Grand Challenges [84].

According to the Report "Rethinking Food and Agriculture 2020-2030-The Second Domestication of Plants and Animals, the Disruption of the Cow, and the Collapse of Industrial Livestock Farming" by the Rethink X Think Tank (September 2019), the world is on the cusp of the most profound and rapid disruption in food production, driven, in part, by advances in precision fermentation and, hence, in our capacity to "program" microorganisms to produce organic molecules. Although it is hard to predict the future of the global food production system, it seems likely that sources of cheap protein (e.g., bacterial, fungal and algal protein, insects) will become more and more common in our diet, due to well-known sustainability issues associated with the consumption of animal meat. Indirectly, this could have a positive effect on the forest-based bioeconomy, as many forests have been cut down to make way for agriculture, mainly to grow soy or establish grasslands to feed livestock for meat production. Since bioeconomy depends on the unceasing supply of high amounts of biomass, it appears logical to pay attention to the possibility of using and/or proactively generating sources of biomass characterized by fast growth and high yields (e.g., microbial biomass).

When discussing the capacity of bioeconomy to offer solutions to the Grand Challenges, climate change attracts the most attention, owing to its potentially devastating 
consequences. Moreover, one of the first promises of bioeconomy was to minimize our dependence on fossil fuels, given the link between the combustion of fossil fuels and climate change. Nonetheless, the issue of the connections between bioeconomy and climate change is complicated, with many elements and dimensions. For instance, the European Commission's Knowledge Centre for Bioeconomy has published a brief on the role of the forest-based bioeconomy in mitigating climate change, stating that a holistic approach and system-perspective (taking into account rates of wood harvest, carbon storage in wood and timber products, soil carbon sequestration and substitution of fossil fuels) are required to properly evaluate such role [85].

The fact that climate change has overshadowed the other global challenges tends to obscure an unquestionable reality, i.e., that the abovementioned challenges are linked and interdependent, pointing out to the imperative need for a holistic approach and an urgent change in the global level of consumption of energy and goods [86]. Within this context, Aguilar and Patermann (2020) [86] emphasized the need to build a global biodiplomacy. The term biodiplomacy can be found in the literature with many different meanings but, for Aguilar and Patermann (2020) [86], the heart of the biodiplomacy concept lies in the need for a holistic approach for the effective and enduring global management of our natural resources. The illusion of unlimited economic growth has often led to so-called "uneconomic growth", when "increases in production come at an expense in resources and well-being that is worth more than the items made" $[86,87]$.

\subsection{Critical Sustainability Issues}

For bioeconomy to offer solutions to the Grand Challenges and collaborate in the achievement of the SDGs, it must be based on sustainability principles; incorporate the circularity, energy-efficiency, renewability and responsible consumption paradigms [88]; and pave the way towards a more sustainable, ethical and prosperous society, building a future in which we live in harmony with nature and ourselves.

If it is to survive in the long-term as a driver of the economy, providing goods and services in an environmentally friendly way, the field of bioeconomy must assimilate the following concepts:

(1) Limits to Growth: The concept of Limits to Growth [89] warns us that we have overshot our limits in many areas by expanding our demands on the Earth's resources and sinks beyond what can be sustained over time, leading us, unless we react, towards collapse [89]. Sustainability does not mean zero growth, but a sustainable society "would ask what the growth is for, and who would benefit, and what it would cost, and how long it would last, and whether the growth could be accommodated by the sources and sinks of the Earth" [89]. Although the debate on the Limits to Growth remains poised between the pessimism of resource constraints and the optimism of technological progress, Jackson and Webster (2016) [90] pointed out that we have learned critical lessons from the Limits to Growth assessment: (i) the dynamics of overshoot and collapse proceed not from the total exhaustion of resources but from an inevitable decline in resource quality; and (ii) regarding the speed and timing of overshoot and collapse, it must be remembered that, at the point at which peaks in production become obvious and declines are imminent, our options are more limited than they are while growth is in progress (i.e., the "Seneca effect": "increases are of sluggish growth, but the way to ruin is rapid"). Marks Bank (2018) [91] highlighted that, under conditions of economic stagnation and incipient environmental crisis, growth needs to be made limited, more fully socialized, and re-conceived in terms that afford greater priority to non-economic values and human prosperity indicators.

(2) Planetary Boundaries: The Planetary Boundaries is a framework that aims to integrate the development of our society and the maintenance of the Earth system in a resilient and accommodating state, by providing an analysis of the risk that human-induced perturbations will destabilize the Earth system [92]. The Planetary Boundaries framework defines a "safe operating space for humanity" [93] based on intrinsic biophysical processes that regulate the stability of the Earth system. Planetary boundaries are being developed [94,95] 
and regularly updated for different Earth system processes (i.e., climate change, biosphere integrity, biogeochemical flows, land-system change, freshwater use, atmospheric aerosol loading, ocean acidification, stratospheric ozone depletion, biological integrity, and novel entities). The anthropogenic perturbation levels of four of such processes currently exceed the proposed planetary boundary: climate change, biosphere integrity, biogeochemical flows, and land-system change [92].

(3) Resilience Thinking: Resilience Thinking is a paradigm based on the resilience concept introduced by Holling (1973) [96] to help understand the capacity of ecosystems with multiple attractors to persist in the original state when subjected to perturbations [97,98]. Holling (1996) [99] also defined engineering resilience, a narrower concept used in many fields to refer to the return rate to equilibrium upon a perturbation. Resilience thinking is focused on the dynamics and development of complex social-ecological systems with three crucial aspects that interrelate across multiple scales: (i) resilience (the capacity of a social-ecological system to continually change and adapt yet remain within critical thresholds); (ii) adaptability (a part of resilience that represents the capacity to adjust responses to changing external drivers and internal processes and then allow for development along the current trajectory); and (iii) transformability (the capacity to cross thresholds into new development trajectories) [100]. Resilience thinking, based on the idea that social-ecological systems have multiple regimes that are separated by thresholds, is about seeing systems, linkages, thresholds, and cycles and understanding and embracing change, as opposed to striving for constancy [101].

(4) Ecosystem services: The Ecosystem Services framework, promoted by the Millennium Ecosystem Assessment [102], balances resource use and conservation according to how societies value the consumptive and non-consumptive services provided by ecosystems [103]. The Ecosystem Services concept is based on the fact that ecosystems provide a wide range of services that are of crucial importance to human well-being [104,105]. This concept reframes our relationship with nature and emphasizes natural assets as critical components of inclusive wealth, well-being, and sustainability [105]. The concept of ecosystem services is a useful approach to bridge the scientific-economic policy-making divide. As such, it is recommended that environmental monitoring programs are based on ecosystem services, thereby providing the best information for decision-making [106]. Building on the Ecosystem Services framework, the concept of Nature's Contributions to People [107] acknowledges the role that culture plays in defining the links between humans and nature and, interestingly, operationalizes the role of indigenous and local knowledge in understanding nature's contribution to people. To clarify the distinction between ecosystem services and nature's contribution to people, Kadykalo et al. (2020) [108] identified eleven conceptual claims about, supposedly, novel elements from the literature on nature's contribution to people. They concluded that five of those claims (i.e., diverse worldviews, context-specific perspectives, relational values, fuzzy and fluid reporting categories and groups, and inclusive language and framing) were truly novel conceptualizations of people and nature relations.

(5) Ecological Footprint: The Ecological Footprint is the amount of biologically productive land required to sustain a population's consumption of natural resources and dispose of their waste products [109]. This concept has been praised as an effective heuristic and pedagogic device for presenting total resource use by humans in a way that communicates easily to almost everyone [110]. Wiedmann and Barrett (2010) [111] reported that ecological footprint can be a powerful tool for communicating the over-consumption of humanity and can act as a convincing statement to communicate sources of unsustainability to the public, as well as to political and corporate decision-makers. The ecological footprint is estimated by adding up different forms of consumption (e.g., food, housing, transportation, and goods), along with generated waste, and then converting that information into a common metric. But unlike economics, which uses money as the main indicator of value, the ecological footprint approach uses productive land area as its metric [112]. 
(6) Environmental Bioethics: The field of environmental bioethics seeks just social arrangements that promote human well-being, while simultaneously preserving the natural environment [113]. Three issues-technology, toxics, and consumption-stay at the core of environmental bioethics. Environmentally, bioethics considers the claims of sustainability as part of the justice equation (for instance, by using "the fair share of biocapacity" as an index of both sustainability and justice) [114]. The field of environmental bioethics poses important questions, such as why we need to protect our environment, what happens if biological species becomes extinct, what respect to nature means, and whether we can use and protect nature at the same time [115]. As an example, the risk of biopiracy must be thoughtfully addressed in bioeconomy forums. The term "biopiracy" refers to unauthorized access to biological material and its use for commercial purposes, sometimes with exclusive monopoly rights (despite the fact that those biological resources might belong to a community, region or another country). Biotheft is a related concept that refers to the illegal or unauthorized exportation of organisms for commercial purposes [116,117]. There is an ongoing debate about the difference between bioprospecting, which is "searching, collecting and deriving genetic materials from biological sources that can be used in commercialized pharmaceutical, agricultural, industrial, or chemical processing end products" [117], and biopiracy (the theft of valuable biological resources for the commercial benefit of developed countries and multinational corporations) [118].

\section{Conclusions}

Great expectations are currently placed on bioeconomy as an economic paradigm that can lead the way towards a more prosperous and sustainable future. Indeed, bioeconomy offers a valuable opportunity to reconcile economic growth with environmentally responsible action. In particular, circular bioeconomy can provide many opportunities for achieving the SDGs, provided it is managed sustainably, and is expected to play an important role in the low carbon economy. If we adopt the broad interpretation of the term (i.e., all economic activities based on the production and conversion of renewable biological resources into products), then it can truly be claimed that bioeconomy dates back to ancient times. After this long journey, bioeconomy is nowadays at an interesting point in time in which it can make the most of recent advancements in biosciences and technology to move forward faster than ever, provided it embraces critical sustainability issues. Finally, the following definition of bioeconomy is proposed here to emphasize some of the aspects discussed in this paper: "The sustainable production and conversion of renewable biological resources and generated wastes into products and services, which fervently embraces ethics and circularity to simultaneously promote human well-being and nature conservation".

Author Contributions: Conceptualization, C.G., A.A. and I.A.; literature review, N.G., I.A. and L.B.; writing-original draft preparation, C.G. and N.G.; writing—review and editing, I.A., A.A. and L.B. All authors have read and agreed to the published version of the manuscript.

Funding: This research received no external funding.

Institutional Review Board Statement: Not applicable.

Informed Consent Statement: Not applicable.

Data Availability Statement: Not applicable.

Conflicts of Interest: The authors declare no conflict of interest.

\section{References}

1. El-Chichakli, B.; Von Braun, J.; Lang, C.; Barben, D.; Philp, J. Five cornerstones of a global bioeconomy. Nature 2016, 535, 221-223. [CrossRef]

2. Issa, I.; Delbrück, S.; Hamm, U. Bioeconomy from experts' perspectives-Results of a global expert survey. PLoS ONE 2019, 14, e0215917. [CrossRef] [PubMed]

3. Frisvold, G.B.; Moss, S.M.; Hodgson, A.; Maxon, M.E. Understanding the U.S. bioeconomy: A new definition and landscape. Sustainability 2021, 13, 1627. [CrossRef] 
4. Delvenne, P.; Hendrickx, K. The multifaceted struggle for power in the bioeconomy: Introduction to the special issue. Technol. Soc. 2013, 35, 75-78. [CrossRef]

5. Goven, J.; Pavone, V. The bioeconomy as political project: A Polanyian analysis. Sci. Technol. Hum. Values 2014, 1-36. [CrossRef]

6. Birner, R. Bioeconomy concepts. In Bioeconomy. Shaping the Transition to a Sustainable Biobased Economy; Lewandowski, I., Ed.; Springer: Berlin/Heidelberg, Germany; University of Hohenheim Stuttgart: Stuttgart, Germany, 2018; pp. 17-38. [CrossRef]

7. Birch, K. The neoliberal underpinnings of the bioeconomy: The ideological discourses and practices of economic competitiveness. Genom. Soc. Policy 2006, 2, 1-15. [CrossRef]

8. Birch, K.; Levidow, L.; Papaioannou, T. Sustainable capital? The neoliberalization of nature and knowledge in the European "knowledge-based bio-economy". Sustainability 2010, 2, 2898-2918. [CrossRef]

9. Gottwald, F.T.; Budde, J. Mit Bioökonomie die Welternähren? Institut für Welternährung-World Food Institute e.V.: Berlin, Germany, 2015.

10. WWF. Industrial Biotechnology - More Than Green Fuel in a Dirty Economy? World Wide Fund for Nature (WWF): Copenhagen, Danmark, 2009.

11. Bastos Lima, M.G. Corporate power in the bioeconomy transition: The policies and politics of conservative ecological modernization in Brazil. Sustainability 2021, 13, 6952. [CrossRef]

12. Bugge, M.M.; Hansen, T.; Klitkou, A. What is the bioeconomy? A review of the literature. Sustainability 2016, 8, 691. [CrossRef]

13. OECD. The Bioeconomy to 2030. Designing a Policy Agenda. Main Findings and Policy Conclusions. 2009. OECD International Futures Project. Available online: www.oecd.org/futures (accessed on 9 July 2021).

14. European Commission. Innovating for Sustainable Growth: A Bioeconomy for Europe. 2012. Brussels, 13.2.2012 COM(2012) 60 final. Available online: https:/ / ec.europa.eu/research/bioeconomy/pdf/official-strategy_en.pdf (accessed on 9 July 2021).

15. Telekom Forum Berlin (Germany), Bioeconomy Council of the German Government. Global Bioeconomy Summit Conference Report, Proceedings of the Global Bioeconomy Summit, GSB2018, Berlin, Germany, 19-20 April 2018; Office of the Bioeconomy Council: Berlin, Germany, July 2018; p. 108.

16. German Bioeconomy Council. Available online: https://www.biooekonomie-bw.de/en/bw/definition (accessed on 9 July 2021).

17. Gawel, E.; Pannicke, N.; Hagemann, N. A path transition towards a bioeconomy-The crucial role of sustainability. Sustainability 2019, 11, 3005. [CrossRef]

18. Pfau, S.; Hagens, J.; Dankbaar, B.; Smits, A. Visions of sustainability in bioeconomy research. Sustainability 2014, 6, 1222-1249. [CrossRef]

19. Peterson, K.; Kaaret, K. Bioeconomy Pathways at National and Regional Levels; SEI Discussion Brief, May 2020; Stockholm Environment Institute: Stockholm, Sweden, 2020; p. 8.

20. Kardung, M.; Cingiz, K.; Costenoble, O.; Delahaye, R.; Heijman, W.; Lovrić, M.; van Leeuwen, M.; M’Barek, R.; van Meijl, H.; Piotrowski, S.; et al. Development of the circular bioeconomy: Drivers and indicators. Sustainability 2021, 13, 413. [CrossRef]

21. European Commission. First Circular Economy Action Plan. 2015. Available online: https://ec.europa.eu/environment/topics/ circular-economy / first-circular-economy-action-plan_en\#: \{\}:text=In\%202015\%2C\%20the\%20European\%20Commission, growth\%20and\%20generate\%20new\%20jobs (accessed on 9 July 2021).

22. Borrello, M.; Pascucci, S.; Cembalo, L. Three propositions to unify circular economy research: A review. Sustainability 2020, 12, 4069. [CrossRef]

23. Brandão, A.S.; Gonçalves, A.; Santos, J.M. Circular bioeconomy strategies: From scientific research to commercially viable products. J. Clean. Prod. 2021, 295, 126407. [CrossRef]

24. Woźniak, E.; Tyczewska, A.; Twardowski, T. Bioeconomy development factors in the European Union and Poland. New Biotechnol. 2021, 60, 2-8. [CrossRef] [PubMed]

25. Gaffey, J.; McMahon, H.; Marsh, E.; Vehmas, K.; Kymäläinen, T.; Vos, J. Understanding consumer perspectives of bio-based products-A comparative case study from Ireland and The Netherlands. Sustainability 2021, 13, 6062. [CrossRef]

26. Zwier, J.; Blok, V.; Lemmens, P.; Geerts, R.-J. The ideal of a zero-waste humanity: Philosophical reflections on the demand for a bio-based economy. J. Agric. Environ. Ethics 2015, 28, 353-374. [CrossRef]

27. Koppejan, D.; Asveld, L. The Public Debate: An Accumulation of Controversies. Getting to the Core of the Bioeconomy: A Perspective on the Sustainable Promise of Biomass; Rathenau Instituut: The Hague, The Netherland, 2011; pp. 55-85.

28. Asveld, L.; van Est, R.; Stemerding, D. Executive Summary. Getting to the Core of the Bioeconomy: A Perspective on the Sustainable Promise of Biomass; Rathenau Instituut: The Hague, The Netherland, 2011; pp. 11-14.

29. Asveld, L.; van Est, R.; Stemerding, D. The Bio-Economy: Fertile Soil for Policy Targets. Getting to the Core of the bio-Economy: A Perspective on the Sustainable Promise of Biomass; Rathenau Instituut: The Hague, The Netherland, 2011; pp. 17-31.

30. Stegmann, P.; Londo, M.; Junginger, M. The circular bioeconomy: Its elements and role in European bioeconomy clusters. Resour. Conserv. Recycl. X 2020, 6, 100029. [CrossRef]

31. Abad-Segura, E.; Batlles-delaFuente, A.; González-Zamar, M.-D.; Belmonte-Ureña, L.J. Sustainability of the joint application of bioeconomy and circular economy: A worldwide trends study. Sustainability 2021, 13, 7182. [CrossRef]

32. Sadhukhan, J.; Sen, S.; Gadkari, S. The mathematics of life cycle sustainability assessment. J. Clean. Prod. 2021, $309,127457$. [CrossRef]

33. Sadhukhan, J.; Ng, K.S.; Martínez-Hernández, E. Biorefineries and Chemical Processes. Design, Integration and Sustainability Analysis; John Wiley \& Sons Ltd.: Chichester, West Sussex, UK, 2014; p. 625. 
34. Diaz-Chavez, R.; Mortensen, S.; Wikman, A. Bioeconomy: Untapping Natural and Human Resources to Achieve Sustainability; Working Paper 2019-nn; Stockholm Environment Institute, Africa Centre: Nairobi, Kenya, 2019.

35. Calicioglu, Ö.; Bogdanski, A. Linking the bioeconomy to the 2030 sustainable development agenda: Can SDG indicators be used to monitor progress towards a sustainable bioeconomy? New Biotechnol. 2021, 61, 40-49. [CrossRef]

36. Bicchielli, C.; Biancone, N.; Ferri, F.; Grifoni, P. BiOnto: An ontology for sustainable bioeconomy and bioproducts. Sustainability 2021, 13, 4265. [CrossRef]

37. Staffas, L.; Gustavsson, M.; McCormick, K. Strategies and policies for the bioeconomy and bio-based economy: An analysis of official national approaches. Sustainability 2013, 5, 2751-2769. [CrossRef]

38. D'Amato, D.; Droste, N.; Allen, B.; Kettunen, M.; Lähtinen, K.; Korhonen, J.; Leskinen, P.; Matthies, B.D.; Toppinen, A. Green, circular, bio economy: A comparative analysis of sustainability avenues. J. Clean. Prod. 2017, 168, 716-734. [CrossRef]

39. Ramcilovic-Suominen, S.; Pülzl, H. Sustainable development-A 'selling point' of the emerging EU bioeconomy policy framework? J. Clean. Prod. 2018, 172, 4170-4180. [CrossRef]

40. Lier, M.; Kärkkäinen, L.; Korhonen, K.T.; Packalen, T. Understanding the Regional Bioeconomy Settings and Competencies in 29 EU Regions in 11 EU Countries. Natural Resources and Bioeconomy Studies 88/2019; Natural Resources Institute Finland: Helsinki, Finland, 2019; p. 28.

41. Bößner, S.; Johnson, F.X.; Shawoo, Z. Governing the bioeconomy: What role for international institutions? Sustainability 2021, 13, 286. [CrossRef]

42. Alexander, D. Bioregionalism: Science or sensibility? Environ. Ethics 1990, 12, 161-173. [CrossRef]

43. Alexander, D. Bioregionalism: The need for a firmer theoretical foundation. Trumpeter 1996, 13, 3. Available online: http: / / www.icaap.org/iuicode?6.13.3.4 (accessed on 9 July 2021).

44. Scarlat, N.; Dallemand, J.-F.; Monforti-Ferrario, F.; Nita, V. The role of biomass and bioenergy in a future bioeconomy: Policies and facts. Environ. Dev. 2015, 15, 3-34. [CrossRef]

45. Hafner, M.; Fehr, L.; Springorum, J.; Petkau, A.; Johler, R. Perceptions of bioeconomy and the desire for governmental action: Regional actors' connotations of wood-based bioeconomy in Germany. Sustainability 2020, 12, 9792. [CrossRef]

46. Meyer, R. Bioeconomy strategies: Contexts, visions, guiding implementation principles and resulting debates. Sustainability 2017, 9, 1031. [CrossRef]

47. Krippendorff, K. Content Analysis: An Introduction to its Methodology, 2nd ed.; Sage Publications: Thousand Oaks, CA, USA, 2004; ISBN 0761915443.

48. Reinheimer, H. Evolution by Co-Operation: A Study in Bio-Economics; Kegan Paul, Trench, Trubner and Co.: London, UK, 1913; p. 200.

49. Lotka, A.J. Elements of Physical Biology; Williams and Wilkins Company: Baltimore, MD, USA, 1925.

50. Bonaiuti, M. Bio-economics. In Degrowth: A Vocabulary for a New Era; D’Alisa, G., Dematia, F., Kallis, G., Eds.; Routledge/Taylor \& Francis Group: Abingdon, Oxon, UK, 2014; pp. 52-55.

51. Georgescu-Roegen, N. The measure of information: A critique. In Modern Trends in Cybernetics and Systems; Ross., J., Bilciu, C., Eds.; Springer: New York, NY, USA, 1977; pp. 187-217.

52. Georgescu-Roegen, N. Matter matters, too. In Prospects for Growth: Expectations for the Future; Wilson, K.D., Ed.; Praeger: New York, NY, USA, 1977; pp. 293-313.

53. Georgescu-Roegen, N. Inequality, limits and growth from a bioeconomic viewpoint. Rev. Soc. Econ. 1977, XXXV, 361-375. [CrossRef]

54. Mayumi, K. The Origen of Ecological Economics. The Bioeconomics of Georgescu-Roegen; Routledge, Taylor and Francis: London, UK; New York, NY, USA, 2001; p. 161.

55. Von Braun, J. Bioeconomy and sustainable development-dimensions. Focus Rural Rural 21 2014, 3, 1-9.

56. Gottwald, F.T. Bioeconomy-A challenge to integrity. In The Common Good and Ecological Integrity: Human Rights and the Support of Life; Westra, L., Gray, J., D’Aloia, A., Eds.; Earthscan: London, UK; Routledge: New York, NY, USA, 2016 ; pp. $22-35$.

57. Enríquez, J. Genomics and the world's economy. Science 1998, 281, 925-926. [CrossRef]

58. Glick, J.L. The industrial impact of the biological revolution. Technol. Soc. 1982, 4, 283-293. [CrossRef]

59. European Commission. Life Sciences and Biotechnology-A Strategy for Europe: Communication from the Commission to the European Parliament, the Council, the Economic and Social Committee and the Committee of the Regions; Office for Official Publications of the European Communities: Luxembourg, 2002.

60. EU Presidency. En Route to the Knowledge-Based Bio-Economy; Cologne Summit of the German Presidency: Cologne, Germany, 2007.

61. OECD. Available online: https://www.oecd.org/science/emerging-tech/biotechnologystatistics-europeanunion.htm (accessed on 9 July 2021).

62. European Federation of Biotechnology. Available online: https://www.oecd.org/fr/sti/tech-emergentes/biotechnologystatisticseuropeanunion.htm (accessed on 9 July 2021).

63. American Chemical Society. Available online: http://www.environmentdata.org/archive/vocabpref:20786 (accessed on 9 July 2021).

64. 64Cherubini, F. The biorefinery concept: Using biomass instead of oil for producing energy and chemicals. Energy Convers. Manag. 2010, 51, 1412-1421. [CrossRef] 
65. Sadhukhan, J.; Dugmore, T.I.; Matharu, A.; Martínez-Hernández, E.; Aburto, J.; Rahman, P.K.; Lynch, J. Perspectives on “game changer" global challenges for sustainable 21st century: Plant-based diet, unavoidable food waste biorefining, and circular economy. Sustainability 2020, 12, 1976. [CrossRef]

66. Sadhukhan, J.; Gadkari, S.; Martínez-Hernández, E.; Ng, K.S.; Shemfe, M.; Torres-García, E.; Lynch, J. Novel macroalgae (seaweed) biorefinery systems for integrated chemical, protein, salt, nutrient and mineral extractions and environmental protection by green synthesis and life cycle sustainability assessments. Green Chem. 2019, 21, 2635-2655. [CrossRef]

67. Sadhukhan, J.; Martínez-Hernández, E.; Murphy, R.J.; Ng, D.K.; Hassim, M.H.; Ng, K.S.; Kin, W.Y.; Jaye, I.F.M.; Hang, M.Y.L.P.; Andiappan, V. Role of bioenergy, biorefinery and bioeconomy in sustainable development: Strategic pathways for Malaysia. Renew. Sustain. Energy Rev. 2018, 81, 1966-1987. [CrossRef]

68. Venkatachalam, L. Environmental economics and ecological economics: Where they can converge? Ecol. Econ. 2007, 61, 550-558. [CrossRef]

69. Van den Bergh, J.C.J.M. Ecological economics: Themes, approaches, and differences with environmental economics. Reg. Environ. Chang. 2001, 2, 13-23. [CrossRef]

70. Georgescu-Roegen, N. The Entropy Law and the Economic Process; Harvard University Press: Cambridge, MA, USA, 1971.

71. Spash, C.L. A tale of three paradigms: Realising the revolutionary potential of ecological economics. Ecol. Econ. 2020, 169, 106518. [CrossRef]

72. Spash, C.L. Social ecological economics: Understanding the past to see the future. Am. J. Econ. Sociol. 2011, 70, 340-375. [CrossRef]

73. Costanza, R. Ecological Economics: The Science and Management of Sustainability; Columbia University Press: New York, NY, USA, 1991.

74. Scales, I.R. Green capitalism. In The International Encyclopedia of Geography; Richardson, D., Castree, N., Goodchild, M.F., Kobayashi, A., Liu, W., Marston, R.A., Eds.; John Wiley \& Sons, Ltd.: Hoboken, NJ, USA, 2017. [CrossRef]

75. Hemmelskamp, J. Environmental Taxes and Standards: An Empirical Analysis of the Impact on Innovation. In Innovations-Oriented Environmental Regulation-Theoretical Approaches and Empirical Analysis ZEW Economic Studies; Hemmelskamp, J., Rennings, K., Leone, F., Eds.; Springer: Berlin/Heidelberg, Germany; New York, NY, USA, 2000; Volume 10, pp. $303-329$.

76. Charter, M.; Clark, T. Sustainable Innovation; Centre for Sustainable Design: Surrey, UK, 2007.

77. European Commission. Competitiveness and Innovation Framework Program (2007-2013), Brussels. 2007. Available online: http: / / ec.europa.eu/cip/ (accessed on 9 July 2021).

78. Oltra, V.; Saint Jean, M. Sectoral systems of environmental innovation: An application to the French automotive industry. Technol. Forecast. Soc. Chang. 2009, 75, 567-583. [CrossRef]

79. Carrillo-Hermosilla, J.; del Rio, P.; Könnöla, T. Diversity of eco-innovations: Reflections from selected case-studies. J. Clean. Prod. 2010, 18, 1073-1083. [CrossRef]

80. Díaz-García, C.; González-Moreno, A.; Sáez-Martínez, F.J. Eco-innovation: Insights from a literature review. Innov. Manag. Policy Pract. 2015, 17, 6-23. [CrossRef]

81. Cluzel, F.; Vallet, F.; Tyl, B.; Leroy, Y. Eco-design vs. eco-innovation: An industrial survey. In Proceedings of the 13th International Design Conference-DESIGN, Dubrovnik, Croatia, 19-23 May 2014; pp. 1501-1510.

82. UN FAO. The State of Food and Agriculture. Livestock in the Balance; FAO: Rome, Italy, 2009; ISBN 978-92-5-106215-9.

83. Bosch, R.; van de Pol, M.; Philp, J. Define biomass sustainability. Nature 2015, 523, 526-527. [CrossRef] [PubMed]

84. Philp, J. The bioeconomy, the challenge of the century for policy makers. New Biotechnol. 2018, 40, 11-19. [CrossRef]

85. European Commission. Brief on the Role of the Forest-Based Bioeconomy in Mitigating Climate Change through Carbon Storage and Material Substitution. Available online: https:/ / ec.europa.eu/jrc/en/science-update/forest-based-bioeconomyand-climate-change-mitigation-trade-offs-and-synergies (accessed on 9 July 2021).

86. Aguilar, A.; Patermann, C. Biodiplomacy, the new frontier for bioeconomy. New Biotechnol. 2020, 59, 20-25. [CrossRef] [PubMed]

87. Daly, H. Ecological economics: The concept of scale and its relation to allocation, distribution, and uneconomic growth. In Ecological Economics and Sustainable Development; Daly, H., Ed.; Edward Elgar: Cheltenham, UK, 2007; pp. 82-103.

88. Aguilar, A.; Twardowski, T.; Wohlgemuth, R. Bioeconomy for sustainable development. Biotechnol. J. 2019, 1800638. [CrossRef]

89. Meadows, D.; Randers, J.; Meadows, D. Limits to Growth: The 30-Year Update; Chelsea Green Publishing Company: White River Junction, VT, USA, 2004; p. 368.

90. Jackson, T.; Webster, R. Limits Revisited-A Review of the Limits to Growth Debate. A Report to the All-Party Parliamentary Group on Limits to Growth, 2016, Creative Commons, CC BYNC-ND 4.0. Available online: http:/ /www.limits2growth.org.uk/ revisited (accessed on 9 July 2021). [CrossRef]

91. Mark Banks, M. Creative economies of tomorrow? Limits to growth and the uncertain future. Cult. Trends 2018, 27, 367-380. [CrossRef]

92. Steffen, W.; Richardson, K.; Rockström, J.; Cornell, S.E.; Fetzer, I.; Bennett, E.M. Planetary boundaries: Guiding human development on a changing planet. Science 2015, 347, 6223. [CrossRef] [PubMed]

93. Rockström, J.; Steffen, W.; Noone, K.; Persson, Å.; Chapin, F.S., III; Lambin, E. Planetary boundaries: Exploring the safe operating space for humanity. Ecol. Soc. 2009, 14, 32. Available online: http://www.ecologyandsociety.org/vol14/iss2/art32/ (accessed on 9 July 2021). [CrossRef]

94. Hughes, T.P.; Carpenter, S.; Rockström, J.; Scheffer, M.; Walker, B. Multiscale regime shifts and planetary boundaries. Trends Ecol. Evol. 2013, 28, 389-395. [CrossRef] [PubMed] 
95. Lenton, T.M.; Williams, H.T.P. On the origin of planetary-scale tipping points. Trends Ecol. Evol. 2013, 28, 380-382. [CrossRef] [PubMed]

96. Holling, C.S. Resilience and stability of ecological systems. Ann. Rev. Ecol. Syst. 1973, 4, 1-23. [CrossRef]

97. Gunderson, L.H. Ecological resilience: In theory and application. Ann. Rev. Ecol. Syst. 2000, 31, 425-439. [CrossRef]

98. Folke, C. Resilience: The emergence of a perspective for social-ecological systems analyses. Glob. Environ. Chang. 2006, 16, 253-267. [CrossRef]

99. Holling, C.S. Engineering resilience versus ecological resilience. In Engineering Within Ecological Constraints; Schulze, P., Ed.; National Academy Press: Washington, DC, USA, 1996; pp. 31-44.

100. Folke, C.; Carpenter, S.R.; Walker, B.; Scheffer, M.; Chapin, T.; Rockström, J. Resilience thinking: Integrating resilience, adaptability and transformability. Ecol. Soc. 2010, 15, 20. Available online: http://www.ecologyandsociety.org/vol15/iss4/art20/ (accessed on 9 July 2021). [CrossRef]

101. Walker, B.; Salt, D. Resilience Thinking. Sustaining Ecosystems and People in a Changing World; Island Press: Washington, DC, USA, 2006; p. 174.

102. MEA. Millennium Ecosystem Assessment, Ecosystems and Human Well-Being: General Synthesis; Island Press: Washington, DC, USA, 2005.

103. Perrings, C.; Naeem, S.; Ahrestani, F.; Bunker, D.E.; Burkill, P.; Canziani, G.; Elmqvist, T.; Ferrati, R.; Fuhrman, J.; Jaksic, F.; et al. Ecosystem services for 2020. Science 2010, 330. [CrossRef]

104. Costanza, R.; d'Arge, R.; de Groot, R.; Farber, S.; Grasso, M.; Hannon, B.; Limburg, K.; Naeem, S.; O’Neill, R.V.; Paruelo, J.; et al. The value of the world's ecosystem services and natural capital. Nature 1007, 387, 253-260. [CrossRef]

105. Costanza, R.; De Groot, R.; Sutton, P.; van der Ploeg, S.; Anderson, S.J.; Kubiszewski, I.; Farber, S.; Turner, R.K. Changes in the global value of ecosystem services. Glob. Environ. Chang. 2014, 26, 152-158. [CrossRef]

106. Burges, A.; Epelde, L.; Benito, G.; Artetxe, U.; Becerril, J.M.; Garbisu, C. Enhancement of ecosystem services during endophyteassisted aided phytostabilization of metal contaminated mine soil. Sci. Total Environ. 2016, 562, 480-492. [CrossRef]

107. Díaz, S.; Pascual, U.; Stenseke, M.; Martín-López, B.; Watson, R.T.; Molnár, Z.; Hill, R.; Chan, K.M.A.; Baste, I.A.; Brauman, K.A.; et al. Assessing nature's contributions to people. Science 2018, 359, 270-272. [CrossRef] [PubMed]

108. Kadykalo, A.N.; López-Rodriguez, M.D.; Ainscough, J.; Droste, N.; Ryu, H.; Ávila-Flores, G.; Le Clec'H, S.; Muñoz, M.C.; Nilsson, L.; Rana, S.; et al. Disentangling 'ecosystem services' and 'nature's contributions to people'. Ecosyst. People 2020, 15, $269-287$. [CrossRef]

109. Wackernagel, M.; Rees, W.E. Our Ecological Footprint. Reducing Human Impact on the Earth; The New Catalyst Bioregional Series 9; New Society Publishers: Grabiola Island, BC, Canada, 1996.

110. Costanza, R. The dynamics of the ecological footprint concept. Ecol. Econ. 2000, 32, 341-345.

111. Wiedmann, T.; Barrett, J. A review of the ecological footprint indicator-Perceptions and methods. Sustainability 2010, 2, $1645-1693$. [CrossRef]

112. Wackernagel, M.; Onisto, L.; Bello, P.; Linares, A.C.; Falfan, I.S.L.; Garcia, J.M.; Suarez, A.L.S.; Guerrero, G.S. National natural capital accounting with the ecological footprint concept. Ecol. Econ. 1999, 29, 375-390. [CrossRef]

113. Fiore, R.N. Bioethics: Environmental. In Encyclopedia of Global Bioethics; Ten Have, H., Ed.; Springer, Springer International Publishing Switzerland: Basel, Switzerland, 2010. [CrossRef]

114. Dwyer, J. How to connect bioethics and environmental ethics: Health, sustainability, and justice. Bioethics 2009, $23,497-502$. [CrossRef] [PubMed]

115. Urker, O.; Yildiz, M.; Cobanoglu, N. The role of bioethics on sustainability of environmental education. Procedia Soc. Behav. Sci. 2012, 47, 1194-1198. [CrossRef]

116. Akurugoda, C.L. Biopiracy and its impact on biodiversity: A critical analysis with special reference to Sri Lanka. Int. J. Bus. Econ. Law 2013, 2, 48-52.

117. Amarasinghe, K.K. Bio-piracy and its impact on biodiversity: A special review on Sri Lankan context. J. Environ. Protect. 2018, 268-275. [CrossRef]

118. Isaac, G.E.; Kerr, W.A. Bioprospecting or biopiracy? Intellectual property and traditional knowledge in biotechnology innovation. J. World Intellect. Prop. 2004, 7, 35-52. [CrossRef] 